\title{
Теплозахист будинків і споруд системами теплолокалізаціі
}

\section{Г. В. Лужсанська}

Одеський національний політехнічний університет, пр. Шевченко, 1, Одеса, 65044, Украина

3 кожним роком проблема енергозбереження в сучасному світі стає все більи $і$ більи актуальною. Енергозбереження передбачає економне витрачання енергетичних ресурсів, тому щзо природні ресурси $\epsilon$ вичерпними, дорого коштують, а їх видобуток в більшості випадків завдає шкоди навколишньому середовищу. Системи життєзабезпечення для комфортного перебування людей в будівлях та спорудах різного призначення $\epsilon$ одними з найбільш значущих споживачів паливно-енергетичних ресурсів. Можливостей для розвитку енергозберігаючих технологій у даній області існує безліч. Один з важливих напрямків у економії енергетичних ресурсів при експлуатації будівель - ие вдосконалення систем захисту тепла будівель та споруд комунальнопромислового сектора. Актуальним є реалізаџія теплозахисту будівель при проривах холодного повітря в опалювальних приміщеннях при відкриванні зовнішніх дверей та воріт. При дослідженні роботи теплолокалізуючого пристрою плоский неізотермічний струмінь, щзо виходить із прямокутного стального насадку, розташованого в площині відкритого зовнішнього отвіра, розбився на безліч маленьких струменів, які поширюються в даному напрямку, витікають з однакових по розміру розтинів з однаковою швидкістю, відокремлені друг від одного на відстані, рівною ширини щелі Була визначена швидкість повітряного потоку, отримані графічні залежності. За допомогою математичного моделювання отримана адекватна картина фізичного процесу витікання. На початковій ділянці відбулося злиття цчих струменів в єдиний повітряний потік, $і$ як наслідок, не виникає проникнення холодного зовнішнього повітря в опалювальні приміщеенн будівель i споруд, тим самим зменшуючи теплову споживану потужність теплолокалізуючого пристрою. В результаті відбувається значне зниження затрат енергетичних ресурсів на систему теплопостачання, поліпшується мікроклімат в приміщенні, збільшується ефективність роботи засобів теплозахисту будівель і споруд.

Ключові слова: повітряно-теплова завіса, плоский повітряний струмінь, енергозбереження, швидкість, теплова енергія.

(C) The Author(s) 2018. This article is an open access publication

This work is licensed under the Creative Commons Attribution 4.0 International License (CC BY) http://creativecommons.org/licenses/by/4.0/

\section{1. ВСТУП}

В Україні проблема енергозбереження 3 кожним роком стає все більш актуальною. У зв'язку 3 обмежністю енергетичних ресурсів відбувається постійне зростання цін на енергоносії. Їх виробництво негативно впливає на навколишнє середовище.

За оцінкою вітчизняних i зарубіжних фахівців, одним 3 основних напрямів поліпшення екологічної обстановки в світі та збереження здоров'я населення $\epsilon$ зниження рівня споживання природних енергетичних ресурсів.

Зниження енергетичних витрат для забезпечення якісної роботи систем теплопостачання комунальнопромислового сектора $\epsilon$ на сьогоднішній день однією 3 найгостріших проблем в Україні і в світі.

У нашій країні на системи опалення та теплопостачання житлових, громадських і промислових будівель витрачається більше 50\% всіх енергоресурсів.

Актуальною проблемою сучасності комунальнопромислового сектора міст i селищ $€$ пошук енергозберігаючих заходів та інженерних рішень по створенню комфортних умов для перебування людини в будівлях i спорудах 3 мінімальними тепловими втратами, а також для поліпшення їх теплозахисту.
Проблеми енергозбереження та зниження втрат теплоти в навколишнє середовище істотно впливають на екологічну ситуацію, техніко-економічні показники і капітальні витрати при будівництві.

\section{2. РЕЗУЛЬТАТИ ДОСЛІДЖЕНЬ}

При реконструкції будівель i споруд різного призначення, а також при їхньому новому будівництві відбувається постійне впровадження енергозберігаючих технологій. При вриванні холодного зимового повітря в опалювальні приміщення будівель і споруд відбувається вихолоджування приміщень, збільшується навантаження на системи теплопостачання i виникає необхідність в застосуванні заходів теплозахисту будівельних об'єктів. Одним з елементів забезпечення енергозберігаючих технологій і теплозахисту будинків при проривах зовнішнього повітря в опалювальні приміщення $\in$ застосування теплолокалізуючих пристроїв.

Повітря нагрівається в повітронагрівачі і у вигляді плоского рівномірного струменю виходить 3 щілинного прямокутного насадку, розташованого уздовж зовнішнього отвору в площині воріт або дверей будівель i споруд різного призначення. 3 метою 
ефективної роботи повітряно-теплових завіс перекриємо отвір витікання сталевими пластинами в переміжному порядку всередині насадка $[1,2]$.

У площині зовнішнього отвору плоский струмінь розбивається на безліч невеликих повітряних потоків, які при злитті утворюють єдиний повітряний потік, запобігаючи проникнення холодного повітря, тим самим зменшуючи теплову споживану потужність теплолокалізуючого пристрою, знижуючи сумарне споживання тепла будівлі і збільшуючи його теплозахист [3].

Розглянмо взаємодію двох плоских неізотермічних струменів, що поширюються в одному напрямку, витікли 3 щілин однакових розмірів 3 однаковою швидкістю, відокремлених один від одного відстанню, рівним ширині щілини. Рівняння для визначення швидкості потоку, утвореного взаємодією двох струменів, має вигляд:

$$
\mathrm{v}^{2}=\mathrm{v}_{1}^{2}+\mathrm{v}_{2}^{2}
$$

де $\mathrm{v}_{1}$ - швидкість потоку, утвореного одним необмеженим струменем, м/с;

$\mathrm{v}_{2}$ - швидкість потоку, утвореного другим необмеженим струменем, м/с;

Визначимо швидкість потоку, утвореного одним струменем на початковій i основній ділянках за формулою Шлихтинга [4]:

- на початковій ділянці:

$$
\bar{V}=\frac{V}{V_{o}}=\left(1-\bar{y}^{1,5}\right)^{2}
$$

де $\mathrm{V}_{\mathrm{o}}$ - швидкість на початку струменя

$\mathrm{V}$ - швидкість в точці, віддаленій від осі струменя на відстані у визначимо:

$$
y=\frac{y}{B_{o}-B_{я}}
$$

де $\mathrm{B}_{\mathrm{o}}$ - полуширина струменя;

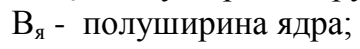

$$
B_{я}=\frac{1-\beta \bar{B} \bar{v}_{n}{ }^{2}}{1-\beta \bar{v}_{n}{ }^{2}}
$$

$\beta=1,56-$ коефіцієнт Буссінеска;

$\bar{v}_{\mathrm{n}}=\mathrm{k}=0,45$ - константа поля швидкостей;

$\bar{B}$ - відносна полуширина струменя;

$$
\bar{B}=1+\bar{s} \operatorname{tg} \Theta_{H}
$$

$\overline{\mathrm{s}}=\mathrm{s} / \mathrm{Bo}-$ відносна абсциса;

$\Theta_{\mathrm{H}}=12^{\circ}-$ кут бічного розширення струменя на початковій ділянці;

$$
\mathrm{y}=\mathrm{y}^{\prime}-\left(\mathrm{y}_{\mathrm{H}}+\mathrm{y}_{\mathrm{\kappa}}\right) / 2
$$

у` - поточна координата по вертикалі, м;

$\mathrm{y}_{\text {н }}$ - початкова координата витікання струменя (низ щілини), м;

$\mathrm{y}_{\text {к }}$ кінцева координата витікання струменя (верх щілини), м.

- на основній ділянці:

$$
\bar{V}=\frac{V}{V_{o c}}=\left(1-\bar{y}^{1,5}\right)^{2}
$$

де $\mathrm{V}_{\text {ос }}$ - швидкість на осі струменів, м/с;

$$
\overline{\mathrm{y}}=\mathrm{y} / \mathrm{y}_{\text {гр }}=\mathrm{y} / \overline{\mathrm{B}}
$$

$\bar{B}$ - відносна полуширина струменя на основній ділянці:

$$
\bar{B}=\bar{s} \operatorname{tg} \Theta
$$

$\Theta=14^{\circ}-$ кут бічного розширення струменя на основній ділянці.

Знаючи початкову швидкість витікання, визначаємо дійсну швидкість окремих струменів повітряного потоку. На рисунку 1 представлено графічне накладення взаємодіючих потоків, яке показало, що струмінь практично зливається в один потік $з$ усталеною швидкістю на відстані 20 см від поверхні витікання. Таким чином, злиття повітряних потоків відбувається на початковій ділянці струменя.

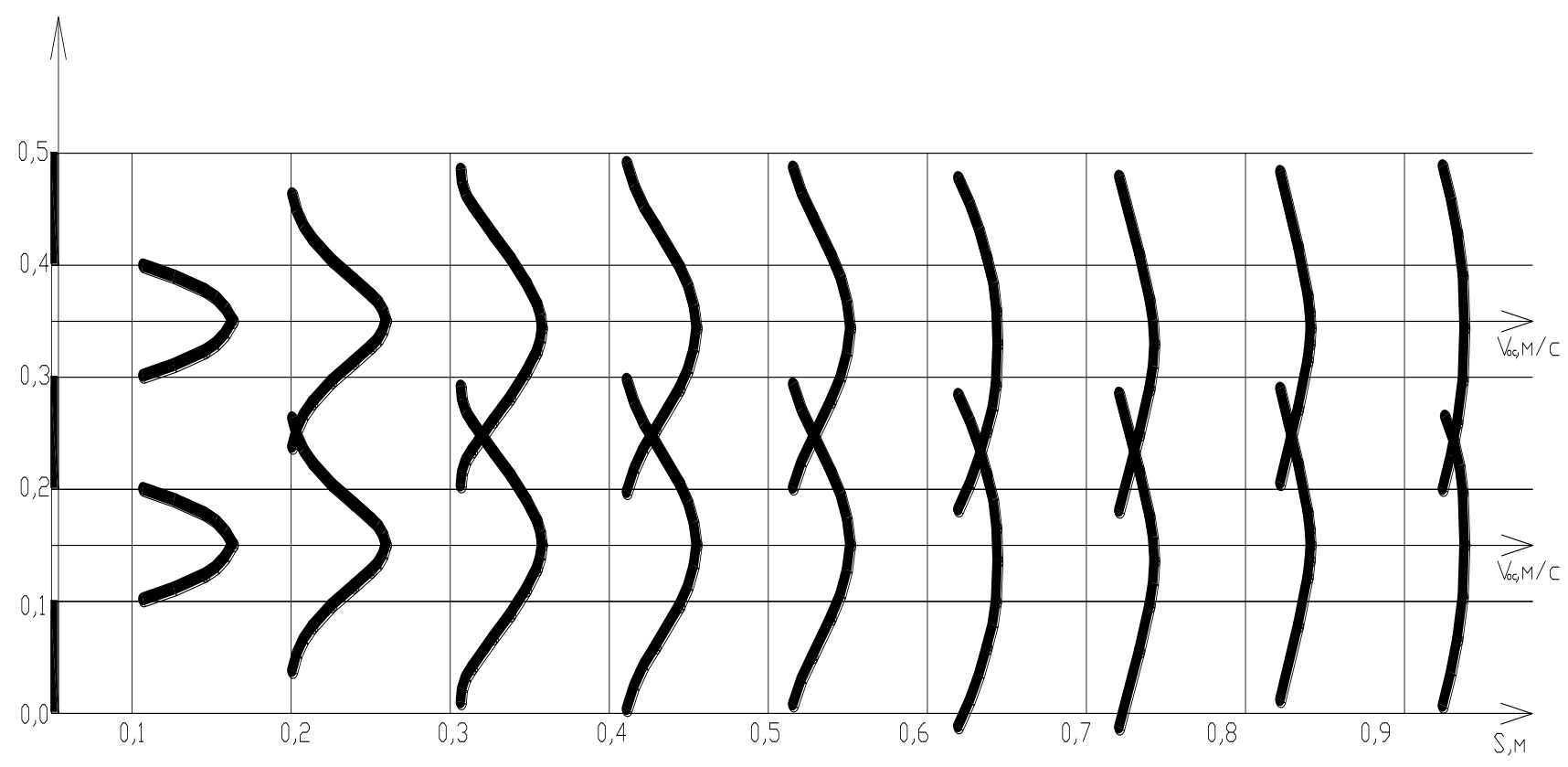

Рисунок 1- Злиття плоских струменів в єдиний потік 
За допомогою математичного моделювання можливо отримання адекватної картини фізичного процесу, тобто зміна фізичних параметрів в просторі і в часі. Оскільки фізичні процеси - результат дії законів фізики, то найбільш адекватні фізичним процесам математичні моделі являють собою систему, відображаючих закони фізики диференціальних або інтегральних рівнянь 3 граничними i початковими умовами, які прив'язують дану математичну модель до поставленої конкретної фізичної задачі [4].

На основі математичного апарату за допомогою програмного продукту COSMOSFIoWorks виконане рішення даного завдання. Програмний комплекс COSMOSFIoWorks базується на останніх досягненнях обчислювальної газо- і гідродинаміки, розраховує широке коло різних течій: двовимірні і тривимірні, ламінарні, турбулентні і перехідні, нестискувані, стискувані, 3 до-, транс- і надзвуковими областями, стаціонарні і нестаціонарні течії багатокомпонентних текучих середовищ в каналах або навколо тіл, 3 урахуванням гравітації, прикордонного шару, в тому числі з урахуванням шорсткості стінок, з теплообміном між текучим середовищем і твердим тілом, яке, в свою чергу, може складаться з декількох матеріалів і ін.

При дослідженні теплолокалізуючіх пристроїв повітряно-теплової завіси за допомогою програми COSMOSFIoWorks була розглянута зміна і розподіл швидкості сумарного повітряного потоку, утвореного злиттям плоских неізотермічних однакових струменів, на вході в опалювальне приміщення будівлі (рисунки 2-3).

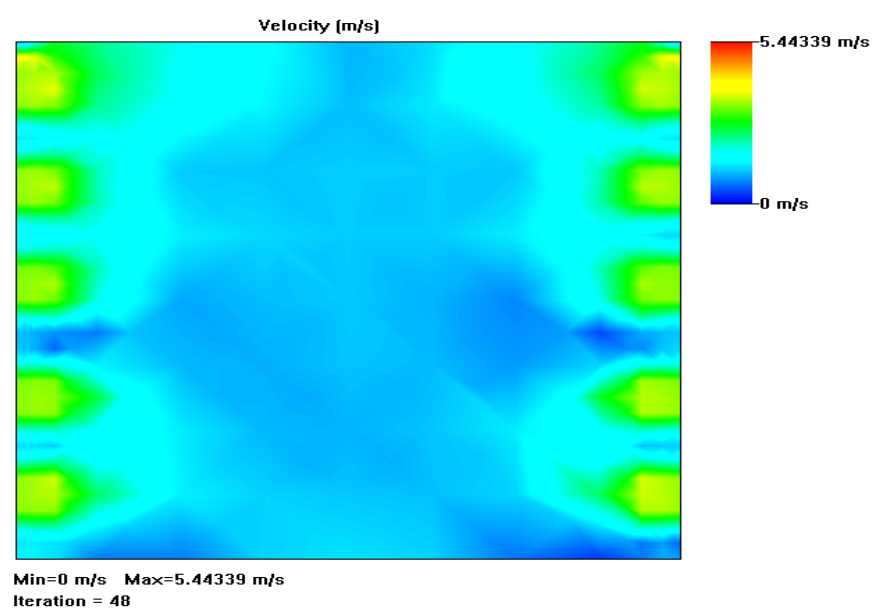

Рисунок 2 - Розподіл швидкості на вході в приміщення при швидкості зовнішнього повітря 1 м/с і швидкості повітря в патрубках $10 \mathrm{M} / \mathrm{c}$

Отримані дослідження показали завихрення, які утворюються за торцями щілинних насадків, при цьому зі збільшенням відстані від точки витікання вони пропадають, потік рухається більш плавно. В результаті зменшується гальмування, знижуються втрати тиску на тертя. Утворюється єдиний повітряний потік 3 рівномірним рухом в сторону запобігання проникнення холодного повітря. На відстані рівному 2,2 від ширини отвори насадку, плоскі струменя зливаються в єдиний потік, що значно скорочує витрату енергоресурсів на систему теплопостачання будівлі, покращуючи його теплозахист.

\section{3. Висновки}

Застосування розглянутої конструкції теплолокалізуючого пристрою у вигляді єдиного повітряного вертикального не ізотермічного струменя, утвореним злиттям безлічі плоских струменів в єдиний повітряний потік на початковій ділянці на відстані 2,2 від ширини отвору витікання, дозволить зменшити споживання енергоресурсів системами теплопостачання для теплового захисту будівель і споруд.

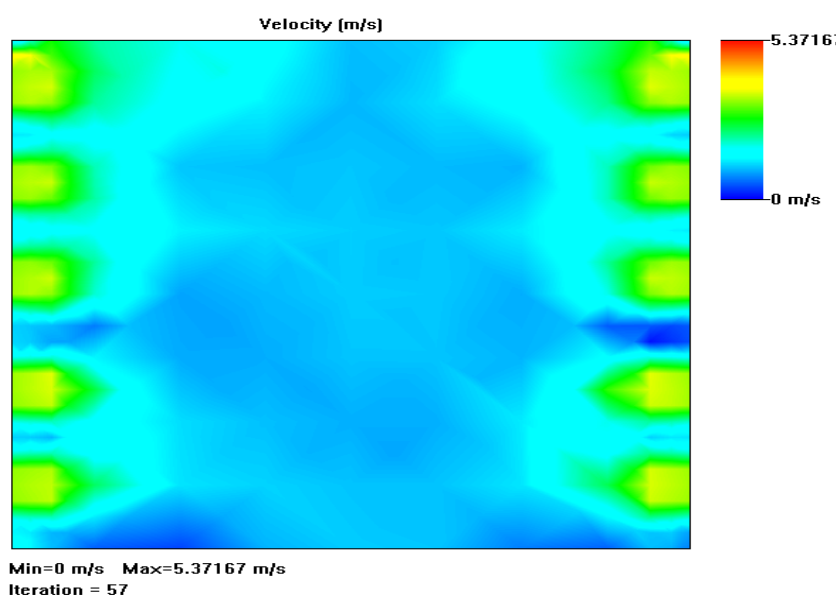

Рисунок 3 - Розподіл швидкості на вході в приміщення при швидкості зовнішнього повітря $1 \mathrm{M} / \mathrm{c}$ і швидкості повітря в патрубках $15 \mathrm{M} / \mathrm{c}$

\section{Література}

1. Г.В. Лужанська, А.С.Денисова. Дослідження систем теплолокалізаціі повітряно-тепловими завісами // Холодильна техніка і технологія. Одесса:- 2016. - №6 (Том 52). - C. 25-28.

2. А.В. Лужанская. Оценка эффективности работы теплолокализующих устройств.// Холодильна техніка та технологія. Том 53. Випуск 4. - Одесса: ОНАХТ. 2017. C. 21-25

3. Патент Украины. UA 64378 A MKI F24F9/00. Способ создания воздушной завесы. /Лужанская А.В., Лужанская И.И. Заявл. 22.05.03; Опубл. 16.02.04, Бюл. №2, $2004-2$ c.

4. Лужанская А.В., Зайцев О.Н., Аэродинамика воздушно-тепловых завес в промышленных зданиях и сооружениях (монография). Научное издание к 50-ти летию НАПКС - Симферополь: НАПКС, СОНАТ 2009 -184 , ISBN 9668111-56-7 


\title{
Thermal protection of buildings and constructions by heat and localization systems
}

\section{G. V. Luzhanska}

Odessa national polytechnic university, 1 Shevchenko av., Odessa, 65044, Ukraine

\begin{abstract}
Every year the problem of energy saving in the modern world is becoming more and more actual.Energy saving involves the very economical use of energy resources, because natural resources are exhaustible, costly, and their production in most cases is harmful to the environment. Life support systems for the comfortable staying of people in buildings and facilities of various purposes are among the most significant consumers of fuel and energy resources. There are many possibilities for developing energy-saving technologies in this area. One of the important directions in saving energy resources in the operation of buildings is to improve the systems of body protection of buildings and structures of the communal and industrial sector. Actual is the realization of thermal protection of buildings in the case of breakthroughs of cold air in the heated premises when opening external doors and gates. This is one of the most important aspects of thermal protection during the installation of heat localization devices installed in open spaces. In the study of the operation of heat localization devices, a flat nonisothermal jet emanating from a rectangular steel nozzle located in the plane of an open external opening was divided into many small jets propagating in the same direction, emanating from slots of the same size with the same speed, separated from each other by a distance equal to the width slit. The air flow rate was determined, graphical dependencies were obtained. With the help of mathematical modeling, an adequate picture of the physical expiration process was obtained. At the initial stage, these streams were merged into a single air flow, and as a result, cold outside air was not allowed to enter the heated premises of buildings and structures, thereby reducing the heat consumption of the heat localization devices. indoor climate, increases the efficiency of the means of thermal protection of buildings and structures.
\end{abstract}

Keywords air-thermal curtain, flat air jet, energy saving, speed, temperature, heat supply systems

\section{References}

1. Luzhanska G. V., Denysova A. E. (2016) Investigation of heat localization by using air-thermal curtains Refrigeration Engineering and Technology, 6(52), 25-28. (in Ukrainian).

DOI: http://dx.doi.org/10.15673/ret.v52i6.470

2. Luzhanska G. V. (2017) Study of heat localization systems by using air-thermal curtains. Refrigeration Engineering and Technology, 4(53), 21-25. (in Ukrainian).
3. Patent of Ukraine UA 64378 A MKI F24F9/00 Luzhanska, G. V., Luzhanska, I. I. Sposob sozdania vozdushnoi zavesy, 2004

4. Luzhanska G.V., Zaicev O.N. (2009) Aerodinamika wozdushno-teplowix zawes $w$ promishlennix zdaniyax $i$ soorujeniyax (monografia), 2009, 184 p (in Russian).

Received 21 May 2018 Approved 03 July 2018 Available in Internet 30 August 2018 